\title{
Improvement of 18 Carat White Gold Alloys
}

\author{
Grahame P. O'Connor
}

BNF Metals Technology Centre, Wantage, England

Although there appears to be scope for the improvement of existing white gold jewellery alloys, the discovery of a radically new alloy seems unlikely. In this article, details are given of one line of approach which resulted in an interesting 18 carat alloy containing nickel, cobalt, iron, chromium and indium.

An ideal 18 carat white gold jewellery alloy should have not only a satisfactory appearance but also appropriate mechanical and other properties which make it amenable to processing by the conventional procedures used in jewellery manufacture. In practical terms, this implies that the alloy should meet all six 'principal' and as many as possible of the 'secondary' requirements listed in Table I.

The majority of commercial 18 carat white gold alloys are based on either the gold-palladium or the gold-nickel systems $(1,2)$. None of these meets the six principal requirements.

\section{Limitations of Existing White Gold Alloys}

Gold-palladium-based alloys are expensive and with their high liquidus temperatures, they are generally used only for wrought items.

Gold-nickel-based alloys are extensively used by the jewellery industry. However, on account of a number of shortcomings, 18 carat nickel white golds are not ideal for all jewellery fabrication purposes.

A major problem is their high hardness typically $270 \mathrm{HV}$ in the annealed condition for a high nickel alloy, coupled with a high workhardening rate (1). Thus, such alloys are not only difficult to cold-work but call for frequent intermediate annealing treatments.

Most commercial nickel white golds also contain zinc and copper. Zinc is used essentially to replace some of the nickel, thereby reducing hardness while maintaining good colour. Because of its volatility, the use of zinc in white gold creates problems in maintaining composition when recycling scrap. The purpose of copper additions is to improve the working properties. Substitution of nickel by either zinc or copper must be strictly limited since more than about 6 per cent zinc results in brittle, unworkable alloys and more than 2 or 3 per cent copper noticeably impairs the colour.
Table I

Requirements for an Ideal 18 Carat White Gold Jewellery Alloy

\begin{tabular}{l|l}
\hline Principal requirements & Known restrictions \\
\hline $\begin{array}{l}\text { Good colour and } \\
\text { reflectivity }\end{array}$ & Low copper \\
\hline $\begin{array}{l}\text { Hardness }<200 \mathrm{HV} \\
\text { and preferably } 120 \text { to } \\
150 \mathrm{HV}\end{array}$ & Limited nickel \\
\hline $\begin{array}{l}\text { Adequate cold } \\
\text { workability, } \\
\text { elongation } \geqslant 25 \\
\text { per cent }\end{array}$ & Limited zinc \\
\hline $\begin{array}{l}\text { Liquidus temperature } \\
\leqslant 1100 \text { C }\end{array}$ & \begin{tabular}{l} 
No refractory metals \\
\hline $\begin{array}{l}\text { Suitable for casting } \\
\text { Competitive cost }\end{array}$
\end{tabular} \\
\hline
\end{tabular}

\begin{tabular}{l|l}
\hline $\begin{array}{l}\text { Secondary } \\
\text { requirements }\end{array}$ & Known restrictions \\
\hline Easy to braze or solder & \\
\hline $\begin{array}{l}\text { Amenable to electro- } \\
\text { plating or electro- } \\
\text { polishing }\end{array}$ & \\
\hline $\begin{array}{l}\text { Resistant to fire } \\
\text { cracking }\end{array}$ & \\
\hline Simple to recycle & No reactive or \\
& volatile metals \\
\hline Easy to polish & \\
\hline Low susceptibility to \\
tarnish and corrosion
\end{tabular}




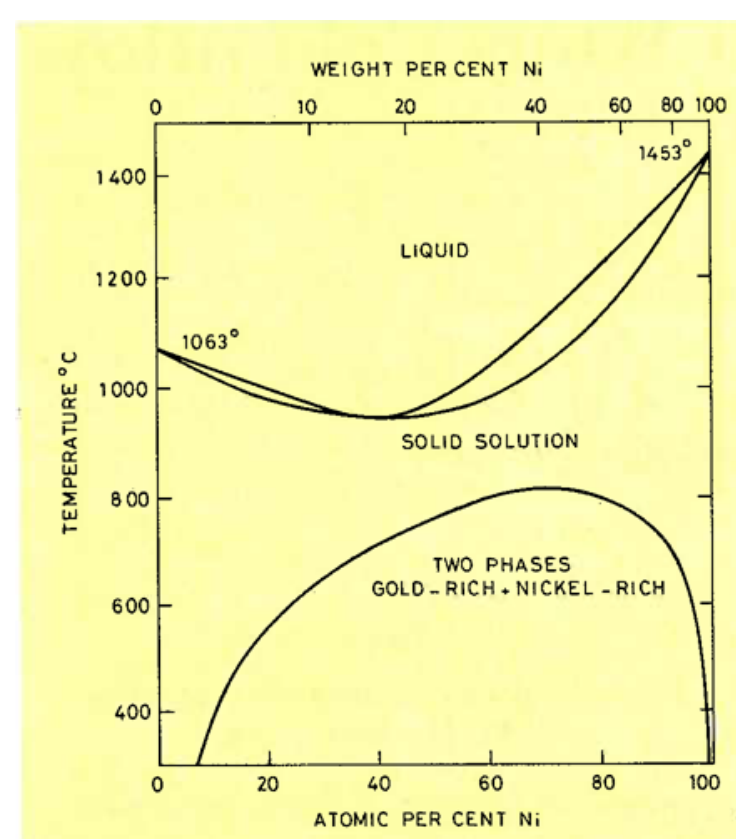

Fig. 1 Equilibrium diagram for gold-nickel alloys. After (3)

The manufacturing jeweller has either to accept the difficulties of the hard, white alloys or to sacrifice good colour for easier workability. In general, the latter situation is favoured and whiteness is achieved by applying a thin electroplated layer of rhodium to the finished article. In use the rhodium layer may wear away and the poor colour of the 'white' gold underneath may then become apparent.

Annealing conventional nickel white golds presents certain difficulties. One is that they tend to oxidise readily to form a greyish film which is not easy to remove chemically. Another is that the annealing temperature must be carefully controlled. The reason for this lies in the goldnickel equilibrium diagram (3) which is illustrated in Figure 1, When an 18 carat alloy is annealed at an intermediate temperature (below about $700^{\circ} \mathrm{C}$ ) in the two-phase region of the equilibrium diagram it decomposes into discrete gold-rich and nickel-rich phases. Two recent papers $(4,5)$ have illustrated this effect which persists in zinc- and copper-containing commercial white alloys. This decomposition can result in a number of unwanted characteristics in the alloy.

One of these is excessive hardness (6). Others are susceptibility to corrosion, to cracking and to 'orange peel' effects on cold-working. These latter effects, as well as impaired colour, become particularly severe if the gold-rich and nickel-rich phases are allowed to coarsen by prolonged heat treatment at an intermediate temperature.
Even when close control of the annealing temperature is achieved, further difficulties in annealing nickel white golds arise because of their tendency to fire-crack, that is to crack spontaneously during annealing after coldworking. This seems to originate from the combined effect of residual stresses from the working operations, stresses arising from changes in microstructure during annealing and stresses caused by uneven thermal expansion resulting from uneven heating. These three stresses acting together can exceed the strength of the material (7), thus leading to fire-cracking. It is thought that the strength of the material may also be reduced locally by precipitation of a weak phase (6), as a further result of the structural changes that can take place in the alloy. Recent work suggests that such changes invariably occur, even at room temperature (8).

Because of these problems, the cold-working and annealing schedule for nickel white golds must be carefully planned. Cold-working must be done so as to minimise internal stresses in the material. Such stresses arise typically from slight deformations which tend to work the surface layers only. For this reason, each cold-working operation should result in a significant reduction and the overall cold deformation should be at least 40 to 50 per cent before annealing so that the alloy is more uniformly stressed throughout its thickness. Annealing must be done at a relatively high and well monitored temperature in a furnace designed to heat evenly. The alloys must not remain for too long at temperatures corresponding to the two-phase region of the equilibrium diagram which means that the work must be cooled fairly rapidly from the annealing temperature, but not so fast that uneven cooling occurs, as this could result in large contraction stresses.

It will be clear from the above that new 18 carat white gold alloys less costly than those based on the gold-palladium system and easier to work than those based on the gold-nickel system would be of great advantage.

\section{Lines of Approach to the Formulation of New 18 Carat White Gold Alloys}

There is little in the technical literature (9) concerning the background to the choice of nickel and palladium as principal whitening agents for 18 carat golds. The possibility of developing a new range of improved white golds based upon the use of other metals as whitening agents could not therefore be excluded.

Many of the properties required of an appropriate alloying element for a white gold can be 
derived from a study of Table I. Since the alloy is to contain only 25 per cent by weight of additions, it follows that any alloying element present in a significant proportion should be a very effective whitener of gold. If the alloy is also to be cold-workable, it follows that it should consist primarily of a gold-based solid solution. To satisfy these requirements any alloying element should have considerable solid solubility in gold. This fact alone restricts the number of potential alloying elements to about twenty (10). If the further constraints that the elements should not be toxic nor excessively reactive are applied, then the choice is limited to the list in Table II. Of these, copper is already known to have little or no decolouring effect on gold (2) and platinum is economically unattractive.

Among the remaining elements in Table II, the bleaching capacities of only silver (11) and of nickel and palladium (12), have been investigated. There appears to be no evidence of a previous systematic exploration of the bleaching capacity of the other potentially useful alloying elements. Such a study was recently carried out by the author (13) in which, for each potential alloying element, three gold-based binary alloys were prepared:

(1) At 5 atomic per cent

(2) At the limit of solid solubility at the annealing temperature or 25 per cent by weight, whichever was smaller

(3) At 25 per cent by weight (18 carat)

In order to identify promising alloying elements for an 18 carat castable white gold, these binary alloys were assessed in terms of the principal requirements for an acceptable white gold alloy (Table I).

None of the 18 carat binary alloys prepared had the combination of properties wanted from a satisfactory 18 carat castable white gold alloy. It therefore follows that an 18 carat white gold alloy must contain more than one additive.

Table III shows some of the relevant properties found with the more dilute binary alloys. All the alloys containing 5 atomic per cent of bleaching element were workable, except gold-titanium. There were noticeable differences in colour, indium, nickel and tin having the greatest whitening effects.

Of the alloys containing a proportion of alloying element equal to the solid solubility limit at the annealing temperature or 25 per cent by weight, whichever was lower, Table III shows that only gold-iron, gold-nickel and gold-palladium were substantially white and cold-workable. These results suggest that, unless gold-iron proves to be a
Table II

Potential Alloying Elements for White Golds

\begin{tabular}{|c|c|c|}
\hline \multirow{2}{*}{$\begin{array}{l}\text { Elements showing } \\
\text { unlimited solid } \\
\text { solubility } \\
\text { at ambient (or } \\
\text { elevated) } \\
\text { temperature }\end{array}$} & \multicolumn{2}{|c|}{$\begin{array}{l}\text { Elements showing } \\
\text { restricted solid solubility at } \\
\text { all temperatures }\end{array}$} \\
\hline & $\begin{array}{l}\text { Two terminal } \\
\text { solid solutions } \\
\text { only }\end{array}$ & $\begin{array}{l}\text { Formation of } \\
\text { intermetallic } \\
\text { compounds }\end{array}$ \\
\hline $\begin{array}{c}\mathrm{Ag} \\
(\mathrm{Cu}) \\
(\mathrm{Ni}) \\
\mathrm{Pd} \\
(\mathrm{Pt})\end{array}$ & $\begin{array}{l}\mathrm{Co} \\
\mathrm{Cr} \\
\mathrm{Fe}\end{array}$ & $\begin{array}{lll}\text { In } & \mathrm{Al} & \mathrm{Nb} \\
\mathrm{Sn} & \mathrm{Mn} & \mathrm{Ta} \\
\mathrm{Zn} & \mathrm{Ti} & \mathrm{V}\end{array}$ \\
\hline
\end{tabular}

suitable system on which to base a white gold alloy, it is unlikely that a radically new 18 carat white gold can be developed. Table III also indicates that chromium, indium, tin and zinc are effective whiteners. Although the addition of these elements in high concentrations results in brittle alloys, they could be useful 'auxiliary' whiteners.

Of the elements identified as poor whiteners, the majority could be rejected for use in an 18 carat white gold because of other disadvantages. The strong oxide formers, aluminium, manganese and titanium, and the elements which tend to increase the liquidus temperature, niobium, tantalum and vanadium were of little interest. Silver and cobalt, although only moderately effective whiteners, formed binary alloys with gold that were relatively soft and workable; hence these elements could be useful additives to a white gold with shortcomings in properties other than colour. This applies also to copper, though to a lesser extent because of its deleterious effects on colour.

These results indicated several lines of approach which could lead to new types of white gold alloy. One such approach was the use of iron as a principal whitener. However, experimental 18 carat white gold alloys based on gold-iron and containing appropriate proportions of other alloying elements were invariably brittle, unless nickel was also present. Another approach was to soften gold-nickel based alloys by incorporating a third element that did not severely impair their colour. This was more successful and goldnickel-cobalt alloys proved to have attractive properties. A further improvement in the combination of colour and hardness was clearly 
Table III

Some Properties of Binary Gold Based Alloys

\begin{tabular}{|c|c|c|c|c|c|c|}
\hline \multirow[b]{2}{*}{$\begin{array}{l}\text { Alloying } \\
\text { element }\end{array}$} & \multicolumn{2}{|c|}{$\begin{array}{l}\text { At low concentration } \\
\text { (5 atomic per cent) }\end{array}$} & \multicolumn{4}{|c|}{$\begin{array}{l}\text { At medium concentration } \\
\text { (limit of solid solubility at annealing } \\
\text { temperature or } 25 \text { wt. per cent) }\end{array}$} \\
\hline & $\begin{array}{l}\text { Decolouring } \\
\text { effect } \\
\text { of the } \\
\text { alloying } \\
\text { element }\end{array}$ & $\begin{array}{c}\text { Hardness in } \\
\text { the } \\
\text { annealed } \\
\text { condition, } \\
\text { HV }\end{array}$ & $\begin{array}{c}\text { Nominal } \\
\text { concentration, } \\
\text { in } \\
\text { wt. per cent }\end{array}$ & $\begin{array}{c}\text { Decolouring } \\
\text { effect } \\
\text { of the } \\
\text { alloying } \\
\text { element }\end{array}$ & $\begin{array}{c}\text { Hardness in } \\
\text { the } \\
\text { annealed } \\
\text { condition, } \\
\text { HV }\end{array}$ & $\begin{array}{l}\text { Cold- } \\
\text { workability }\end{array}$ \\
\hline $\mathrm{Ag}$ & None & 24 & 25 & $\begin{array}{l}\text { Moderately } \\
\text { strong }\end{array}$ & 34 & Excellent \\
\hline Al & " & 38 & 1.5 & Very slight & 71 & Poor \\
\hline Co & " & 52 & 1.6 & None & 52 & Excellent \\
\hline $\mathrm{Cr}$ & $\begin{array}{c}\text { Just } \\
\text { perceptible }\end{array}$ & 40 & 13.0 & Complete & 177 & Impossible \\
\hline $\mathrm{Fe}$ & . & 39 & 16.0 & $\begin{array}{l}\text { Nearly } \\
\text { complete }\end{array}$ & 119 & Satisfactory \\
\hline In & Very slight & 35 & 5.5 & Moderate & 133 & Impossible \\
\hline $\mathrm{Mn}$ & None & 38 & $1.5^{*}$ & None & 38 & Excellent \\
\hline $\mathrm{Nb}$ & " & 50 & - & - & - & - \\
\hline $\mathrm{Ni}$ & Very slight & 44 & 14.0 & $\begin{array}{l}\text { Nearly } \\
\text { complete }\end{array}$ & 254 & Excellent \\
\hline $\mathrm{Pd}$ & None & 30 & 25 & Complete & 100 & $"$ \\
\hline $\mathrm{Sn}$ & Slight & 43 & 5.0 & Moderate & 74 & Impossible \\
\hline $\mathrm{Ta}$ & $\begin{array}{c}\text { Just } \\
\text { perceptibie }\end{array}$ & 28 & 7.4 & $\begin{array}{l}\text { Just } \\
\text { perceptible }\end{array}$ & 28 & Excellent \\
\hline $\mathrm{Ti}$ & ". & 164 & 1.3 & " & 164 & Poor \\
\hline $\mathrm{V}$ & ." & 54 & 25.0 & Strong & 185 & Impossible \\
\hline $\mathrm{Zn}$ & None & 34 & 6.3 & Moderate & 122 & Satisfactory \\
\hline
\end{tabular}

necessary, however, if alloys of this type were to be commercially useful.

With the aim of achieving such an improvement, additional experimental 18 carat alloys were fabricated and assessed. These alloys were based on a gold-nickel-cobalt alloy containing 17.5 per cent nickel and 7.5 per cent cobalt, in which some of the nickel and cobalt were replaced by various amounts of one of the previously identified useful auxiliary additions. Figure 2 illustrates schematically the effects on the colour and hardness of the alloy resulting from the incorporation of various amounts of indium, tin or zinc. Figure 3 gives similar information for alloys containing silver, chromium, copper or palladium. In addition the position of a hard commercial nickel white gold in the annealed condition is indicated for reference. The colour scale of Figures 2 and 3 has been constructed so that 0 represents pure white and 100 represents the colour of fine gold. Advice from manufacturing jewellers indicates that alloys with a colour index of 20 or less would be acceptable as 'white' jewellery alloys which would not necessarily need to be rhodium plated. The position of alloys with an ideal combination of colour and hardness has also been indicated in Figures 2 and 3.

From these figures, it is evident that only indium, tin and chromium significantly improved both colour and hardness. However, tincontaining alloys tend to be brittle and therefore of no use for jewellery purposes. Incorporation of both indium and chromium in gold-nickel-cobalt alloys resulted in a further improvement in the combination of properties, especially if iron was also added in place of some of the nickel. 
Fig. 2 Effects on the hardness and the colour of 18 carat alloys 75 gold/17.5 nickel/7.5 cobalt weight per cent, when one of indium, tin or zinc replaces some of the nickel and cobalt. The colour index is constructed so that 0 indicates a purewhite metal and 100 indicates fine gold. The locations on this graph of a commercial alloy 75 gold 17.3 nickel $/ 2.2$ copper $/ 5.5$ zine, and of white gold alloys with what is currently believed to be the optimum combination of colour and hardness are indicated for reference purposes

Fig. 3 Effects on the hardness and the colour of 18 carat alloys 75 gold/17.5 nickel/7.5 cobalt weight per cent, when one of silver, chromium, copper or palladium replaces some of the nickel and cobalt. The representation is otherwise identical to that in Figure 2
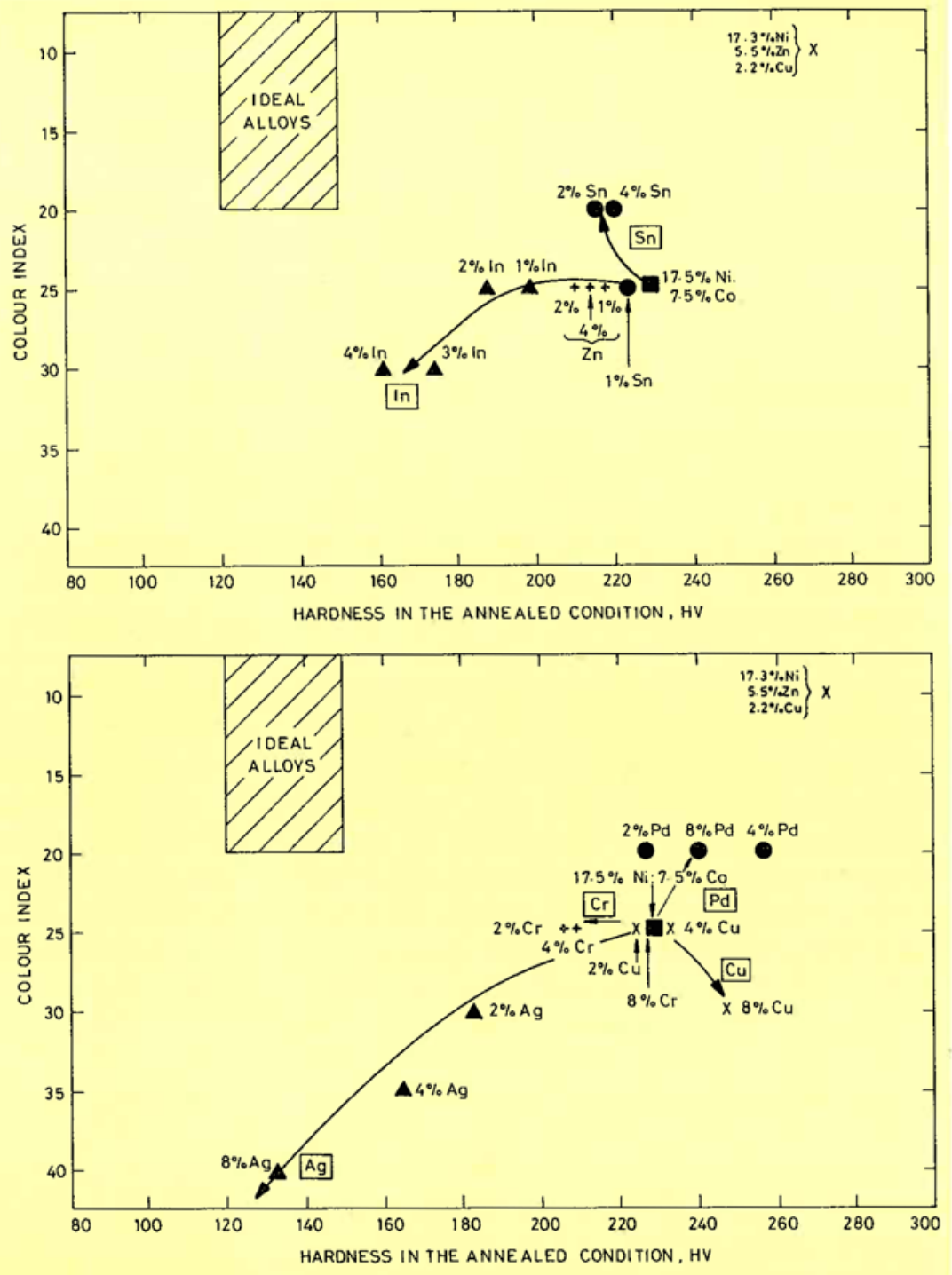

\section{Conclusions}

A systematic study of all the potential useful alloying elements for an 18 carat white gold revealed that only nickel and palladium yielded alloys with properties approaching those required by jewellers. However, auxiliary alloying elements not normally used in such alloys were identified and an investigation of the effects of these elements in gold-nickel based alloys resulted in a promising 18 carat white gold containing nickel, cobalt, chromium, indium and iron.

\section{Acknowledgements}

The author is grateful to the Chamber of Mines of South Africa, the International Gold Corporation Limited and BNF Metals Technology Centre for permission to publish this article and to the former two organisations for financial support for this work. The author also wishes to acknowledge guidance from the Goldsmiths' Research Foundation throughout the course of the research.

\section{References}

1 E A Smith, 'Working in Precious Metals', N.A.G. Press Ltd., London, 1933

2 E. M. Wise, 'Gold: Recovery, Properties and Applications', D. van Nostrand Co. Inc., Princeton, 1964

$3 \mathrm{M}$. Hansen and $\mathrm{K}$. Anderko, 'Constitution of Binary Alloys', McGraw-Hill, New York, 1958

4 E. Stagno and M. R. Pinasco, Mem. Sci. Rev. Metall., 1976, 73, 35-55

5 E. Stagno and M. G. Ienco, Mem. Sci. Rev. Metall., 1976 73, $117-140$

6 E. M. Wise, Trans. Am. Inst. Min. Metall. Eng., 1929, 83, $384-404$

7 P. E. Gainsbury, 'An Investigation into Fire Cracking of an 18 Carat White Gold Alloy', Project Report No. 6a/1/S to the T.A.C., Worshipful Company of Goldsmiths, London, 1970

8 O. F. Kimball and J. B. Cohen, Trans. TMS-AIME, 1969, 245, 661-669

9 J. B. Atkinson, 'The Bleaching of Gold to Produce White Gold - A Literature Survey', Project Report No. 6a/2 to the T.A.C., Worshipful Company of Goldsmiths, London, 1972

10 G. V. Raynor, Gold Bull., 1976, 9, (1), 12-19

11 W. Köster and R. Stahl, Z. Metallkde, 1967, 58, 768-777

12 K. E. Saeger and J. Rodies, Gold Bull., 1977, 10, (1), 10-14

13 G. P. O'Connor, to be published 